\title{
3
}

\section{Beyond the National: How the EU, OECD, and World Bank Do Family Policy}

\author{
Jane Jenson
}

In recent decades, numerous international organizations adopted positions that use components of a policy frame familiar from family policy at the national level. They sought to advance one or more of three classic goals of that domain: stabilizing demography, ensuring income security, and supporting parents' labor force participation (Saraceno, 2018, p. 443). The policy instruments promoted included income transfers, services, and leaves (Daly, in this volume). They were justified variously in the name of equality, social development, or social investment. This chapter examines three such organizations. The Organisation for Economic Co-operation and Development (OECD) and the World Bank are standard international organizations (IO), being intergovernmental. They are composed of independent member countries and they have no institutions to impose policy choices, although each has a range of policy tools that can compel, induce or encourage their members to act in particular ways. The European Union (EU) is not a standard IO. While it does have substantial intergovernmental dimensions, it is also in significant ways a supranational organization. It is a grouping to $27(28)^{1}$ member states that have transferred a measure of sovereignty to European-level institutions, thereby providing them some legislative,

\footnotetext{
${ }^{1}$ With the withdrawal of the United Kingdom from the European Union, the number of members drops to 27 .
}

J. Jenson $(\bowtie)$

Université de Montréal, Montréal, QC, Canada

e-mail: jane.jenson@umontreal.ca 
executive, and regulatory capacity. This transfer touches, moreover, on policy domains important to families and family policy.

Family policy has had moveable boundaries. Goals have changed over time and instruments sidelined. Concerns about demography, whether family planning or pronatalist initiatives, have come and gone as an objective. More permanently sidelined is the principle of redistributing economic resources horizontally from families without children to those raising children. That goal underpinned post-1945 family policy for decades, and generated many countries' choice of universal family allowances to supplement family income. The objective of interfamily horizontal redistribution is currently much less present, often replaced by the goal of vertical redistribution from rich to poor families and means-tested benefits intended to reduce disadvantaged families' risk of poverty. Finally, there is an on-going shift from income maintenance for male breadwinners to measures promoting labor force participation of mothers and shared family care (Bonoli, 2013).

This chapter sets the boundaries of analysis by concentrating on these three goals_-stabilizing demography, family income security, and parental labor force participation. It focuses in particular on the expressed policy goal(s), the targets, and policy instruments highlighted by the organizations and the policy frame used to justify each. In the past decades, each organization has modified its position on all three as well as weighting each differently. The chapter proceeds as follows. First, it provides a brief overview of the three organizations, setting out the policy capacity of each. The next three sections examine the position of each with respect to the three goals. A brief conclusion offers some general discussion of differing trajectories but a shared process leading to non-familialization.

\section{Purpose, Competence, and Actions of Three International Organizations}

The OECD, the World Bank, and the EU have achieved the authority and independence to identify and frame policy problems, using their claims to expertise to prompt their preferred responses. This chapter adopts the analytic stance that ideas and actions of IOs result from the behavior of policy advocates and entrepreneurs within them as much as or even more than from outside pressure. While there is no space in this chapter to trace the influence of internal advocates and entrepreneurs, the premise implies that IOs never simply act at the behest of their principals (for discussions of this literature, see Ellinas \& Suleiman, 2011; Mahon \& McBride, 2008; Weaver, 2007). 
One of a number of international organizations created in 1944 to ensure postwar reconstruction in Europe and Asia, the World Bank's official name is International Bank for Reconstruction and Development. Over the next decades, however, its mission of reconstruction fell away, and it now seeks to be the world's premier development institution, its credo being "our dream is a world free of poverty." There are two vectors to the Bank's work. One is operational, involving the elaboration of country-specific projects. The Bank provides financial resources via loans for project or policy directions and technical expertise to governmental and other agencies, usually with conditions about policy design and implementation. Decisions about such loans require large numbers of Bank staff in both Washington and the field (King, 2007, p. 161). The second vector developed later because "... no systematic research program existed until the early 1970s” (King, 2007, p. 162). The disciplinary training of this research staff has expanded slightly, including both some noneconomists and a wider range of policy expertise, including education and health economists, among others (King, 2007). The Bank's work nonetheless remains heavily influenced by economists and their analytic frames (Rao \& Woolcock, 2007).

The OECD's Convention, signed in Paris in December 1960, commits it to promoting policies meant to achieve the "highest sustainable economic growth and employment and a rising standard of living in Member countries, ... thus to contribute to the development of the world economy ...."2 This international agreement gave the OECD "... no regulatory capacity, no independent source of funds, no money to lend, and no instruments within its control" (Wolfe, 2008, p. 28). Nevertheless, Article 3 of the Convention did provide a pillar on which the OECD has built its intellectual leadership; it requires member countries to furnish the information and data necessary for the staff to undertake analytic work. Building on these data and the possibilities for analysis and comparison they provide, the OECD has flourished as a knowledge organization with a large research capacity dominated by economists (Mahon, 2019, p. 3). It has refined techniques for the surveillance of member countries' economic performance and outcomes and provides its members with standardized comparative data, “... aimed at shaping the ideas and preferences...” (Leimgruber \& Schmelzer, 2017, p. 24). It is also a forum for exchanging ideas and policy prescriptions across the international community of experts that circle around the staff, their meetings, and their consultations. Without the possibilities of but also the constraints from

\footnotetext{
${ }^{2}$ The text of the convention can be read online: https://www.oecd.org/general/conventionontheorgani sationforeconomicco-operationanddevelopment.htm (Last accessed on March 27, 2020).
} 
operational projects that restrain the World Bank, the OECD can act with suppleness to refocus its analytic lens quickly (Jenson, 2017a).

The European Union has greater authority over its member states than any standard IO; indeed, the EU is in large part a supranational organization. It has legislative power and a court that can impose conformity to Union law. Bureaucratic structures tasked with action encase its research functions. Moreover, the large bureaucracy is composed of citizens of all member states with a wide range of training and education that tends to follow the traditional expertise of each policy domain as well as varying by national traditions of postsecondary education (Ellinas \& Suleiman, 2011). Since the 1957 Treaty of Rome, the mix of supranational and intergovernmental competences has altered and the influence of the EU in additional policy areas has expanded considerably. Social policy, and thus family policy, is one such area. This expansion occurred over a number of decades, as European institutions pushed the definitional boundaries of their treatygranted competences (Anderson, 2015, pp. 4-5). Within the general area of social policy, the EU deploys several governance practices: "Social regulation means setting legal standards and norms in social policy at the EU level. Hard coordination is EU-facilitated policy coordination that is legally binding and that involves high surveillance and enforcement of member state policy. In contrast, soft coordination is EU-facilitated policy coordination that, while including surveillance, involves weak enforcement" (De la Porte, 2018, p. 478). As we will see below, while some of the components of family policy use the tools of social regulation (for some policies governing parental employment), most involve soft coordination instruments for shaping labor markets and welfare states. Diffusion of ideas within policy communities is also an aim, with these communities defined to include social partners (employers and unions) as well as civil society organizations (De la Porte, 2018, pp. 479, 482-483). Despite much activity, the EU does not "make" much social or family policy, however. It influences national decisions, to be sure, via its diffusion of learning, by its fiscal decisions, and by its limited regulatory authority, but the power to choose, establish and maintain the bulk of social policy remains primarily a national prerogative. The EU's trajectory in the domain of family policy is, therefore, complex and opaque. 


\section{The EU: "An Actor Without a Role"3}

In the treaty-based division of powers in the European Union, the principle of subsidiarity continues to apply to most of what might be family policy, meaning that it remains a national or subnational competence (Anderson, 2015, p. 4). Moreover, member states carefully guard their policy autonomy in the field. Nonetheless, the EU has a long history of acting on objectives of demography, income security, and parental employment, often undertaking these actions without a family policy frame, however.

Substantial consequences for both income security and parental employment, for example, follow from legislative and judicial decisions around the fundamental right to freedom of movement within the Union, one of the four freedoms at its heart. European institutions have developed family law and policy that constrain member states' treatment of migrant families, including the rights of all family members, and the social benefits to which they are entitled. Such interventions arose because promotion of workers' mobility after the Treaty of Rome immediately raised matters touching on the rights of other family members, both adult and children, to reside with the worker in another member state and their access there to social protection benefits and services. Regulations and court decisions extended the right of residence in another member state to accompanying family members, including a spouse, children, and other dependent relatives. Subsequent years brought regulations granting migrants access to the same social and tax advantages as nationals of the member state (for a list see Anderson, 2015, p. 90). Attention also turned to child support and custody in cases of divorce involving several member states (Stalford, 2002). All of these issues, informed by more or less traditional understandings of family, were decided within the framework of the right to freedom of movement upon which the parents' employment and the family's income security rested.

The EU began to sidle further into the field of family policy with the Social Action Programme in 1974, using the door provided by its competences over labor markets. In the name of achieving "full and better employment in the Community," among several objectives listed were actions to achieve equality between women and men and "to ensure that the family responsibilities of all concerned may be reconciled with their job aspirations" (Ross, 2001, p. 180). These actions' target was women, and particularly their equal pay and protection from discrimination because the equal treatment of women and men rested on solid legal grounds, from both the Treaty of Rome (article 119)

${ }^{3}$ Title adopted from Ross (2001). 
and key Directives in the mid-1970s (Hantrais, 1995, p. 80; Jacquot, 2015, pp. 31-35). Over the next years, the policy linkage tightened between equal opportunities and access to childcare services and leaves in order to allow mothers to take up and retain employment.

The Equal Opportunities Unit housed in Directorate-General V (dealing with employment and social policies, now Directorate-General for Employment, Social Affairs and Inclusion DG EMPL) pushed for childcare and leaves, setting up an expert network in 1986; in 1991 its name became Network on Childcare and Other Measures to Reconcile Work and Family Responsibilities. The Equal Opportunities Unit and expert networks around it framed better childcare and improved leaves as policy tools for promoting gender equality in family relations. Greater sharing of family responsibilities was the mechanism to work social change (Ross, 2001, pp. 180-187; Stratigaki, 2004). Given the treaty-based requirement to stay resolutely anchored to the employment field, the measures for reconciliation of work and family remained firmly focused on parental (usually seen as mothers') employment.

In the 1980s, however, the EU began to consider developing an explicit family policy, the entry point being demographic challenges, conceptualized as threats to the functioning of labor markets but also to families' income security. In a 1983 Resolution the European Parliament called for family policy to become "an integral part of all Community policies" (quoted in Hantrais, 1995, p. 80). Policy research and discussion began within various agencies, driven by the widespread demographic concerns of member states. ${ }^{4}$ The 1988 European Council established high-level consultations with officials from member states; the next year the Commission released its Communication on family policies (for more of this story see Ross, 2001, pp. 188ff.). The document presented a broad and ambitious analysis, "because as children are becoming more rare, the demographic future of Europe rests with the family" (EU Commission, 1989, p. 12). It began by painting the "disturbing demographic situation in Europe" and ended with a portrait of the "fundamental role of the family as the basic unit of society" and important for intergenerational solidarity. Between these two visions was analysis of family transformations reshaping demography and labor markets, particularly rising rates of women's labor force participation and marriage patterns. The communication justified EU-level advocacy of childcare services-"a key component of family policy." The Communication's purpose was to make a case for Europe deploying a family policy frame for new and "feasible" action

\footnotetext{
${ }^{4}$ Demography troubled the EU in the 1980s but member states—and demographers-had pointed to falling birth and fertility rates from the mid-1960s and the end of the baby boom (Jenson \& Sineau, 2001, pp. 21-22). For contemporaneous data see Hantrais (1997, pp. 346-347).
} 
(EU Commission, 1989, p. 3). The Social Affairs Council that received the report toned it down somewhat, however, pushing the analysis of childcare back onto "reconciliation" of work and family (and thus the EU's mandate for employment) rather than framing it as a tool for changing gender relations in the family as the Commission had done. It agreed the EU might take action with respect to freedom of movement and equal opportunities, but otherwise the EU would engage in information gathering and diffusion. The European Observatory on National Family Policies began data gathering in 1989 but, as its name indicated, EU actors were well aware that profound ideological differences existed among member states and that they were not about to cede the policy field to the Union.

Nonetheless, European actors moved decisively onto the social policy field in conjunction with the 1992 Treaty of Maastricht (Daly, 2008). While doing so, they continued to identify improving the demographic situation as integral to the EU's purpose because of the threats from both aging (and early retirement practices) and falling fertility. ${ }^{5}$ The Commission published several major reports on demography over these years (EU Commission, 1994, 2006). Well into the new century, European institutions highlighted demographic challenges (falling fertility, aging populations, more diverse family structures) as policy drivers. Policy treatment remained primarily confined, however, to areas of European competence over the operation of labor markets and equal opportunities. The EU pushed policies directly related to childbearing (leaves and childcare) as well as those demographers assume have indirect effects on fertility, such as gender equality and working time (Daly, 2020; Nieuwenhuis, Need, \& van der Kolk, 2012, Chapter 6).

Through the years, the European institutions prescribed support for parental employment. The key theme initiated in the 1980s and worked on through the decades remained supporting parental employment in ways that would permit "reconciliation," particularly for women (for the documents and their summaries see Hantrais, 1997, p. 340; Jenson, 2008; Ross, 2001, pp. 14-15). The EU used its treaty-provided tools assiduously. Instruments of social regulation were deployed in a number of directives (pregnant workers and working time, 1990; parental leaves, 1995) as well to prevent gender-based discrimination. Soft coordination applied to the key service identified as enabling reconciliation of work and family-childcare services (De la Porte, 2018, p. 479). The Lisbon Agenda in 2000 and subsequent

\footnotetext{
${ }^{5}$ Article 7 of the protocol on social policy annexed to the treaty instructed the Commission to report annually " $\ldots$ on progress in achieving the objectives of Article 1 , including the demographic situation in the Community."
} 
declarations set targets for women's employment rate and for childcare services.

Nonetheless, as many have observed, the EU often simultaneously deploys more than one paradigm, often promoting the same policy instrument to attain multiple objectives (Knijn \& Smit, 2009 for example). These alternative perspectives exist in flexible compromise. When the 2000 Lisbon Agenda opened the third "growth spurt" for European social policy, a paradigm that gained prominence diagnosed social exclusion as the main challenge (Daly, 2008, p. 3). The Lisbon Agenda announced the need to "modernize" social policy to make benefits sustainable and promote social inclusion. The policy sources and actors driving this approach were not the same as those that had led the thrust for quality childcare and parental leaves, a push that had come from the Equal Opportunities Unit and the expert, often feminist, networks around them. The Lisbon Agenda's take on social exclusion had different roots: "... the multi-faceted understanding of social exclusion developed through the EU-funded poverty programs and Observatory on Policies to Combat Social Exclusion during the 1980s and 1990s, a turn to activation on the part of the EU (as expressed especially through the European Employment Strategy), and the strong promotion of mobilization by the 'poverty sector'..." (Daly, 2008, p. 6). Adoption of a social inclusion lens was the signal that a social investment strategy was taking shape, and attention to equality both between women and men and across classes was on the sidelines (Cantillon \& Van Lancker, 2013; Jenson, 2009; Saraceno, 2015).

One of the foundational documents of the social investment perspective, A New Welfare Architecture for Europe, prepared for the Belgian presidency in the second half of 2000, sought to concretize principles of the Lisbon Agenda and its lens of inclusion while also incorporating the ambient demographic concerns. In this perspective, if social policy did not succeed in "harmonizing motherhood with employment," three negative consequences were likely: higher child poverty; "labour shortages or, alternatively, a shortage of birth"; and "wasted human capital" when well-educated women without access to nonfamilial childcare limited their labor force participation (EspingAndersen, et al., 2002, pp. 9-10). As the social investment perspective developed through the 2000s, not families but children became the target. In the Commission and Council's annual Joint Reports on Social Inclusion, over time "poverty in general has been almost excised," while child poverty emerged as a "strong issue" (Daly, 2008, p. 10). Indeed, combatting child poverty became a highlight of the European Union's 2008 Renewed Social Agenda, under both the heading "Children and Youth - Tomorrow's Europe" and "Combating Poverty and Social Exclusion" (Jenson, 2009, p. 459). 
When the Social Investment Package was finally issued in 2013 it called for breaking the "intergenerational transmission of disadvantage" and actions to "prepare" not "repair." With its life-cycle approach, children were a central focus and childcare was in the first instance for them and only secondarily for parents (Jenson, 2017b, p. 277). "Access to early childhood education and care (ECEC) has positive effects throughout life, for instance in terms of preventing early school leaving, improving employment outcomes, and facilitating social mobility. ECEC is key to addressing challenges faced by disadvantaged children by providing early intervention. Furthermore, it is essential in removing barriers to the labour market participation of parents" (EU Commission, 2013, p. 21). In this major document, families received little attention except to note that earning adequate income was a challenge for families and they needed family-friendly workplaces and employment policies. ${ }^{6}$

By 2018 when the EU laid out a Pillar of Social Rights in 20 principles, attention to families again was hard to find. The only mention that Europeans might live in families came with respect to income security, in the form of the need for "adequate minimum wages" (principle \#6). Women and men had the right to equal treatment and equal pay while "all groups" must have equal opportunities (principles \#2 and \#3). Then in what was a fundamental turn away from representations of childcare in earlier decades, it became an intervention only for the young: "children have the right to affordable early childhood education and care of good quality" and "the right to protection from poverty," while children "from disadvantaged backgrounds have the right to specific measures to enhance equal opportunities" (EU Commission, 2018). A major policy instrument for family policies for years would no longer serve its double purpose of supporting children's development and the employment of their parents. This discussion of non-parental care was also silent on any goal of changing family relations.

Yet at the same time and in parallel, the Commission announced a directive on work-life balance for parents and carers that returned to familiar and solid ground with respect to parental care (Daly, 2020, Chapter 7). It picked up principles \#2 and \#3 of the Pillar, and promised better implementation of the principle of equality between men and women with regard to labor market opportunities and treatment at work (EU, 2019). The directive extended rights for paternity leave, parental leave, and carer's leave. Thus, alongside the Pillar that focused on individuals and children was a parallel

\footnotetext{
6"Families" and "family" were rarely mentioned in the Social Investment Package, while "child" and "children" received numerous mentions (EU Commission, 2013). The quote here is the only mention of parents.
} 
move finally to address the needs of adults caring for children and others, improvements intended both to encourage sharing of care between women and men and to maintain rates of labor force participation. The directive was firmly anchored by the EU's traditional frame and competence for economic growth: "... this is not only about strengthening the rights of individuals. The new rules are a model for how to align social and economic priorities." 7

\section{The OECD: The Work-Family Nexus}

In 2017 the Secretary-General of the OECD gave a speech in Seoul titled "Better family policies can help combine work and family commitments: Lessons from OECD countries" and another in 2018 in Montreal, "Familyfriendly policies a key driver of economic growth." ${ }^{8}$ The OECD's mission is large- "to promote policies that will improve the economic and social well-being of people around the world"-with economic growth being the primary goal. Yet it has none of the EU's institutional capacity to legislate or to regulate. Indeed, the OECD does not have policies; it has positions and analytic frames that allow it to promote some policies and instruments. Both the Secretary-General's recent speeches singled out good practices in some member countries, a familiar strategy in the OECD's provision of intellectual leadership in processes of social learning (Wolfe, 2008, pp. 25, 41). This embrace of family policy instruments to achieve the IO's economic growth mandate had been a long time coming. It is only in the new millennium that family-friendly or family policies received significant analytic attention, with the aim of increasing employment rates and reducing poverty, especially among lone-parent families. Given this context, this section tracks when and how the OECD interpreted the three classic components of family policy as germane to its mission.

Fully a decade and half after its creation, the OECD established the Directorate for Employment, Labour and Social Affairs (DELSA) in 1974. It convened a first meeting of social affairs ministers only in 1988. DELSA is an overarching directorate that does statistical and analytical work on social protection within sections covering employment, social policies, migration, and health. In the 1980s, when the EU was creating space for social policy

\footnotetext{
7"Work-life balance: Commission welcomes provisional agreement" https://ec.europa.eu/social/main. jsp?langId=en\&catId=1311\&furtherNews=yes\&newsId=9285 (Last accessed 27 Mar 2020).

${ }^{8}$ For the first, see http://www.oecd.org/els/family/better-family-policies-can-help-combine-work-andfamily-commitments.htm (Last accessed 20 Apr 2020). The second is at https://www.oecd.org/new sroom/family-friendly-policies-a-key-driver-of-economic-growth.htm (Last accessed 20 Apr 2020).
} 
action and even explicitly contemplating doing family policy, DELSA was still attached to its "welfare as burden" stance that shaped its analyses (and others' appreciation of it as fundamentally neoliberal). By the early 1990s, however, OECD analysts began to vaunt social expenditures' role in maintaining social cohesion and even serving as investments (Deacon \& Kaasch, 2008, pp. 227-229; Jenson, 2017a, p. 212).

The report New Orientations for Social Policy (OECD, 1994) participated in the widespread reboot of thinking of social policy from income maintenance to instruments to facilitate labor market participation (Bonoli, 2013). Social affairs ministers deliberated on this new approach in 1992, hearing that the socioeconomic context was one of slow growth, labor-market problems, economic insecurity, and tight budgets for social programs. The search for effective and efficient social policies would have three challenges different from those of the post-1945 years: population aging, less familiar family structures, and continuing high rates of women's employment. Moreover, the difficult economic conditions of high unemployment and poverty meant "young families - which are often over-represented among those with low incomes - are finding it difficult to fulfil all their aspirations for their children." In other words, the demographic situation was both a risk for and a consequence of the economy. The major challenge the OECD saw was effects on pension sustainability and care for the vulnerable elderly. These concerns drove most of the search for new orientations. Nonetheless, the gesture toward "aspirations" was a reminder that falling fertility was troubling, and the ministers approved "a review of the wide range of policies in support of families and children."

Four years later the high-level conference Beyond 2000: The New Social Policy Agenda brought ministers together with invited experts. The choice of experts guaranteed that the ministers would hear about the components of family policy, from fertility through parental employment and adequate income. Gøsta Esping-Andersen, as he would four years later for the Belgian Presidency of the EU, argued that "family and labour market policies can no longer be based around the notion of the male breadwinner; such a framework fails to take account of the needs of two-earner households, and can therefore even inhibit family formation and functioning" (OECD, 1997, p. 9). Chiara Saraceno (ibid.) analyzed three shifts in family behavior with consequences for social policies-women's rising labor force participation rate; higher rates of unstable marriages; and declining fertility rates. All three put pressure on traditional family practices of care.

\footnotetext{
${ }^{9}$ See the report of the meeting of the Employment, Labour and Social affairs Committee at ministerial level, Paris, 8 and 9 December 1992. SG/PRESS(92)94.
} 
The emphasis on care continued with the next meeting whose theme was a "new social policy agenda for a caring world." The draft document sketched a troubling situation on its first line: "The demographic challenge to social policy arises from declining fertility and greater longevity. The key point is that there will be fewer people of working age for every person who is retired" (OECD, 1998, p. 2). Pension and health costs were still driving concerns but so was the need for employment-oriented social policies. A lifecourse approach to social policy was deemed appropriate. Drawing directly on Saraceno's earlier analysis, a short section on family formation declared the male-breadwinner model of family relations "outmoded" and enumerated restructured fertility and marital relations, including the increase in loneparent (or what the OECD terms single-parent) families (OECD, 1999, pp. 14-18). With the life-course frame came attention to early childhood interventions of many kinds-from childcare to visits from social workers, targeted to the most disadvantaged, as in the United States from whence the data came (OECD, 1999, pp. 84-86). Data analysis also identified different cross-national patterns in mothers' labor force participation and the effects of social policies on lone parents' employment. All this appeared beneath the heading "reconciling paid work and unpaid work," a formulation in line with the notion that care (unpaid work) was a key challenge. The section focused on leaves and childcare (OECD, 1999, pp. 88-90). Later discussion of policy analysis for "adapting to family developments" hemmed and hawed about a number of instruments and interventions that might be used to keep social protection costs down (OECD, 1999, pp. 135-136). Childcare services were a possible policy instrument, but the OECD's major concern was the "problem" of lone parents: their poverty and the "inconsistent policy signals" some governments gave by subsidizing them to care and not requiring them to seek employment. In addition, family planning and sex education to avoid teen pregnancies were positively mentioned (OECD, 1999, p. 136). Consideration of care for the frail elderly appeared in sections on health policy, however, thereby sidelining unpaid care by family members. The OECD was still having trouble making the analytic leap from aging societies and dependency ratios to a structured approach to family policy that would consistently support employment and ensure adequate income.

By the start of the new decade, the OECD's stance on family matters was taking clearer shape. DELSA was in the midst of the review of the wide range of policies in support of families, called for a decade earlier. One product was the five Babies and Bosses volumes providing a review of the reconciliation of work and family life and the implications for social and labor market trends. In 2007 the final report synthesized the approach for the OECD's main 
business: "If parents cannot achieve their desired work/family life balance, not only is their welfare lower but economic development is also curtailed through reduced labour supply by parents. A reduction of birth rates has obvious implications for future labour supply as well as for the financial sustainability of social protection systems. As parenting is also crucial to child development, and thus the shape of future societies, policy makers have many reasons to want to help parents find a better work/family balance" (OECD, 2007, p. 217).

Throughout the Babies and Bosses series DELSA remained firmly focused on labor force participation while combining all three of the components of standard family policy, although the preferred vocabulary was "familyfriendly" policy (for example OECD, 2007, p. 16). Instruments promoted were publicly supported (albeit not necessarily provided) childcare, parental leaves of a length that would not impede a return to employment and with a design to encourage sharing, various tax measures and some transfers, and flexible workplace measures. The synthesis report criticized policies that allowed, even encouraged, lone parents to remain out of the labor force, retaining the idea of "moderate benefit sanctions" for not seeking work, an idea that had been part of the OECD's toolbox since the 1990s (Mahon, 2008, p. 265; OECD, 2007, p. 20).

Parallel to DELSA's work on the Babies and Bosses series was the Education directorate's Starting Strong analyses, sparked by the 1996 meeting of education ministers whose theme was "Making Lifelong Learning a Reality" and whose final communiqué prioritized improving access to and quality in ECEC. The series was an important element of the OECD's move to a childcentered social investment approach (Jenson, 2017a, p. 213). Located in the Education directorate, the resulting analyses in five reports focused on the supply, forms, and training for ECEC. Parental employment was simply a driver of demand while the next generation's reduced poverty and boosted social mobility could result from successful programming (Bennett, 2006; OECD, 2017). The focus on child protection and child well-being continued in Doing Better for Children, which called for careful and planned investments across the "child life cycle." The document deployed a "well-being" lens, reviewed the evaluation data for a wide range of policy interventions and recommended concentrating spending early, even in utero, and on at-risk children in order to change the intergenerational transmission of disadvantage (OECD, 2009, pp. 178-183).

DELSA's work on supporting families and promoting family-friendly policies resumed in Doing Better for Families, returning to demographic concerns and family income (OECD, 2011a). Recommendations for interventions 
targeted making work pay and supports for work-family balance as well as early interventions especially for young children at risk of developmental delays and socio-emotional difficulties. This analysis also underpinned work on indicators and data development, including the creation of huge databases on family policies and outcomes (Adema, del Carmen Huerta, Panzera, Thevenon, \& Pearson, 2009). Then, two other analyses reported simultaneously. The International Futures Programme that usually tackles issues like space and risks from climate and other disasters, focused on families in the next decades (OECD, 2011b). The report examined large drivers of change and the challenges generated, and pointed to the need for preparation, explicitly framing issues as ones of family policy, in part via the composition of its steering group. Its "taking the long view" section identified a likely scenario of continuing constraints on public finances that would generate pressure for replacement of universal services by targeted ones and a reassignment of responsibilities from the public to the private or community sectors and among individuals, the family and the state (OECD, 2011b, pp. 35-36). A second initiative that continued the emphasis on contributions of effective family policies to economic growth was the organization-wide "gender initiative" launched in 2010. Among policies promoted in the areas of education, employment, and entrepreneurship were familiar "family-friendly" ones such as childcare and parental leaves, including incentives for parental sharing of care in the name of equity (Adema, 2014, pp. 124-125).

All of these efforts typifying the OECD's mandate to "promote policies" lay behind the Secretary-General's two speeches cited above. They continue to inform the work of this IO as it develops a new overall strategy for inclusive growth in response to rising inequalities worldwide (Jenson, 2017a, p. 215). Of the three international organizations examined here, the OECD remains most firmly anchored to a consideration of the three elements of family policy. But this may change as it shifts its analytic lens in the next years.

\section{The World Bank: Population, Women, Children... and Families?}

The World Bank took longer than the other two IOs to pursue sustained analytic attention to social policy design, setting up its Social Development Network in 1997 and publishing the first full-Bank Sector Strategy Paper (SSP) on social development in 2005 (Vetterlein, 2007, pp. 516-517). In earlier years, only a few projects received loans to advance social development goals for health, education, or nutrition. In the 1980s, social lending 
narrowed, with loans to countries being conditional on policies favoring economic restructuring over social spending, under influences similar to those that had produced the OECD's "welfare as burden" stance. When this strategy's human costs appeared, additional tools, including "social funds" (sometimes termed "social investment funds") targeted projects concentrated on creating earning opportunities, social and economic infrastructure, and some social services. Later decades brought other strategies. In none was family policy explicitly evoked, although over the decades several initiatives touched significantly on the three components of the domain, particularly stabilizing the demographic situation. Indeed, in the mid-1990s the Bank claimed it was "among the largest sources of financing for population and reproductive health programs" (World Bank, 1995, p. 4).

Major Bank interventions to reduce fertility started early. "A positive population policy seemed to be the overwhelmingly sensible course of action and was widely adopted starting in the mid-1960s" (Robinson \& Ross, 2007, p. 424). Population growth had been troubling economists close to the Bank since the 1950s; leading figures, including Gunnar Myrdal and the team of Ansley Coale and Edgar Hoover, informed the IO's research and policy (Robinson \& Ross, 2007, p. 3). The institution moved decisively, however, only when Robert McNamera became president in 1967. A first loan to support family planning policies and interventions (1970, in Jamaica) received approval (King, 2007). By the 1980 World Development Report, the Bank's established position was that human development depended on reducing fertility. This was not "an end in itself" - a caveat repeated several times in the WDR - but an action that followed from as well as promoted a range of other positive outcomes (World Bank, 1980, p. 97; see also Razavi in this volume). Policy instruments for family planning were multipurpose, meant to promote health, reduce poverty, and support economic growth and social development.

This perspective on population control was not without its detractors. Feminists and other advocates of women's reproductive rights and health pressed for strategies to end women's subordination rather than simply providing, incentivizing, or imposing contraception (some methods of which were dangerous) and even sterilization. ${ }^{10}$ The Bank in the 1990s did finally accept a reproductive-rights frame, but nonetheless continued to treat financial incentives as a useful instrument to structure clients' family-planning choices (Chowdhury et al., 2013, Chapter 2, p. 58; for a critique see

\footnotetext{
${ }^{10}$ Chowdhury et al. (2013, Chapter 2) discuss in some detail the ethical concerns of practices prior to the 1994 Cairo conference, which was a turning point in international thinking (see also Smyth, 1996).
} 
Smyth, 1996). Environmentalists with a "limits to growth" view of the earth's carrying capacity advocated family planning as a policy instrument for managing population size. The Bank adopted this position, in opposition to the US government whose domestic politics were rife with controversy over abortion and contraception and which claimed that promoting economic growth was sufficient (Ringel, 1993; Whitworth, 1994, Chapter 4). Third, some religious forces were simply pronatalist. None of these positions linked demography to classic family policy frames, however, with the quite limited exception of feminist positions that also argued for women's employment rights. They used a gender equality frame rather than a parental employment one, however. The Bank continued to treat family planning primarily within a health frame, thereby generally leaving it detached from other elements of family policy such as supporting parental employment or ensuring adequate family income.

Nonetheless, elements of other family policy objectives did appear, for example, in the major publication intended to correct popular views of the Bank as enthralled by the Washington Consensus-Investing in People. The World Bank in Action (World Bank, 1995). Laying out the Bank's approach to human development and overseen by the Directors of the Education and Social Policy Department and the Population, Health and Nutrition Department the document began this way: "Investing in people means helping people invest in themselves and their children. It means empowering households, especially poor households, to increase the quantity and quality of investments in children. For people to break the cycle of poverty and improve their lives, they must have access to adequate social services..." (World Bank, 1995 , p. 3). The emphasis on reducing fertility with family planning instruments remained central. But attention also went to strategies to "increase the demand for smaller families" that policy communities believed would follow from health improvements and lower infant mortality, better access to education (particularly for girls), and reduced poverty and higher incomes, all described as broad social policy goals relating to family welfare (World Bank, 1995, p. 10). Nevertheless, analytic interest in the welfare of families or even household units was much less evident than were concerns about health, about partnerships for community development, and even about gender equity.

As the Bank adopted the social investment perspective in the 1990s and 2000s, it moved along two main policy tracks, with each exhibiting no more than partial sensitivity to classic family policy matters. On a first track, the policy work complemented the usual foci on family planning and schooling with a push for early child development (ECD) programs. The outcome 
sought was improved "human capital," with educational interventions back into preschool being the preferred policy instruments to combat the effects of childhood poverty and health problems, including malnutrition. The Bank's policy entrepreneurs drew on research that reported efficiencies from investments in improving school readiness (via preschool and health) and by supporting disadvantaged groups as well as allowing siblings (older sisters for the most part) to remain in school (Jenson, 2017a, p. 210). This was a childfocused analysis. Like the OECD's Starting Strong series, the Bank's ECD work drew on expertise in child development and children's health, rather than on family policy's concern with ensuring parental employment and adequate income. It focused more on girls than adult women and more on the children's social mobility that ECEC might foster than on ensuring adequate family income. It was a pro-poor argument but one that was, as so much of the social investment perspective, more future-oriented than concerned with families in the present.

The second policy track for the social investment perspective clearly targeted family income. Beginning in the late 1990s, a new policy instrument complemented efforts to achieve the pay-offs of investments in ECD and to battle poverty, including its intergenerational transmission. These were conditional cash transfers (CCTs). They transfer money to mothers who fulfill a certain number of conditions with respect to prenatal health and use of health and education services by their children. Countries instituted CCTs with the encouragement and support of the Bank. Indeed, they were a key policy instrument about which the Human Development Network of the Bank deployed vast amounts of social knowledge, expertise, and large loans. By 2015 all Latin American countries had at least one CCT and between 2008 and 2010 the number of cash transfer programs in Africa went from 21 to 37 (Jenson, 2017a, p. 210; see also Chapter 10 by Filgueira and Rossel in this volume). CCTs emerged as a policy innovation in the 1980s in several Latin American countries but in 1997 Mexico created the CCT that we now associate with the social investment perspective. The World Bank quickly joined the CCT bandwagon, offering technical expertise and funding for the extension of these instruments across Latin America (Jenson \& Nagels, 2018). While Bank technocrats continued to praise the Mexican CCT, primarily because it had been designed to provide reliable evaluation data, the version that was standardized and diffused owed more to the Brazilian Bolsa Família that imposed lighter conditions and used a less neoliberal discourse (Jenson, 2017a, p. 211).

Targeted to the very poor, CCTs were designed to increase the disposable income available to families to invest in their children. Mistrustful of men 
and assuming mothers would "invest" more in their children, designers of CCTs paid the transfer to mothers (Jenson \& Nagels, 2018, pp. 332-333). This done, however, there was no control over spending and older children and fathers could benefit from the higher family income (for a discussion see Fiszbein \& Schady, 2009, p. 183). Objectives included reducing children's participation in work, which clearly interfered with human capital acquisition. Bank economists were also fearful that a transfer imposing no employment conditions would encourage parents to reduce their own labor force participation; no such findings were corroborated (Fiszbein \& Schady, 2009, pp. 117-119). Finally, the economists were also afraid families would increase their fertility, in order to maintain access to a CCT, but again numerous evaluation studies detected no such pattern (Fiszbein \& Schady, 2009, p. 121).

Recent Bank analysis has not brought all three components of family policy together, even when work is the analytic target. The 2019 WDR report, for example, examined changing patterns of work, described the Bank's human capital indicators project in detail, reiterated the need for ECD interventions, and approvingly noted CCTs do not reduce employment (World Bank, 2019, pp. 56-57, 73-76, 108). The analysis, nonetheless, while describing many workers, students, and young children living in poor families, does not target the family for interventions. The WDR carefully explored the links between various kinds of social protection and workers' needs, called for more state responsibility for provision and explored possible policy mixes, including a universal basic income. But as with recent EU policy pronouncements, recipients were framed as individuals without families or even children. The section on working women simply remarks that ECD that offers childcare might affect mothers' decisions about employment, while another short paragraph mentions the effects of unpaid domestic labor and the advantages of parental leaves (World Bank, 2019, pp. 75, 97). Overall, however, gender inequalities are ascribed to legal and other discriminations rather than family circumstances. While the Bank has long addressed demographic concerns and poverty, it has rarely put them together with employment to frame them as family policy.

\section{Conclusion}

How might we understand the differences in these three IOs' treatment of the goals of family policy listed at the start of this chapter? The OECD remained committed longer than the other two IOs to family-friendly policies 
promoting mothers' employment and income supplementation in response to demographic concerns. Its All on Board. Making Growth Happen (OECD, 2014) continued to highlight policies for reconciliation and income support as well as the challenges of demographic change (OECD, 2014). In other words, even the shift to an inclusive growth focus on inequalities did not marginalize the family interests of this IO. Nonetheless, the innovative New Approaches to Economic Challenges (NEAC) project, run out of the Secretary-General's office from 2012 to 2015, may sideline the family frame. It was an interorganizational (with the Ford Foundation) and crossorganizational way of working. Fully 14 directorates or centers and numerous committees were acknowledged project participants (OECD, 2015, p. 2). The result was a panoramic overview with significantly thinner consideration of families. The final synthesis reviewed at the ministerial level folded all family-friendly policies (childcare, leaves, working time) into a single paragraph focused on gender (not families) while identifying ECEC as a support for higher PISA scores (OECD, 2015, pp. 42-43).

This example reveals again the effect of bureaucratic location and the knowledge base that comes with it, because each brings a way of seeing, a policy frame and preferred instruments. Over almost two decades the OECD's DELSA jousted with alternative knowledge located in the Directorate for Education. Babies and Bosses "saw" working parents, couples making fertility decisions and poor families, where the Starting Strong experts "saw" young (even unborn) children needing early interventions in order to achieve transitions to school and school success. Disadvantaged family circumstances threatened that success and ECEC (alongside other interventions) might counter it. When both the education and the social directorates were thrown in with 12 units framing "new approaches" they had to contend with other economists' often more familiar frames for economic growth, and were forced back to stripped-down individualized versions of their policies.

The OECD was not alone in experiencing such processes of nonfamilialization. In the EU, too, frame competition occurred. The emerging social investment perspective turned the lens from families, women, and children toward poor children, bringing into the mix other frames and instruments. In addition, the EU's organizational decision to move responsibility for gender from a social DG to one concerned with human rights resulted in greater reliance on a discrimination frame and away from even a reconciliation one (Jacquot, 2015, Chapter 5). Non-familialization of the Pillar of Social Rights was one result. Nonetheless, the EU is a large bureaucratic organization and the search for bridges to consensus across policy frames is 
the standard way of working, as the 2019 directive on work-life balance indicated well. Thus, gender and family policy advocates concerned with women's employment, family income and demography may be able to retain a toehold in a political context in which paradigm plurality is the norm.

The World Bank's way of working is different yet again. Its large bureaucracy dominated by economists manages to retain separate spheres, cocooning child development apart from departments dealing with monetary transfers, and those concerned with family planning. The lack of cross-reference to each other's frames is notable. This is now particularly remarkable with respect to the objective of stabilizing demography. In the mid-1990s family planning was fully entwined with health, education, and nutrition, reflecting that moment's limited but still integrated bureaucratic structure for the social sector. With the expansion of the Human Development Network over the next two decades, the cross-network ties significantly loosened. It was possible to provide a detailed analysis of CCTs that never mentioned family planning and addressed high fertility only as a possible (but ultimately not demonstrated) negative consequence of cash transfers to mothers. Concerns about unequal gender relations in the family were confined to the effects on girls' schooling (Fiszbein \& Schady, 2009). When the 2019 WDR, for its part, analyzed "working women," only 10 lines went to what the OECD calls "family-friendly" policies.

Thus, analytic frames matter within any large organization. The story of these three IOs is both one of change and one in which the popularity of child-centered social investment has frequently trumped all three of the components of family policy that this chapter has followed, thereby fostering non-familialization.

\section{References}

Adema, W. (2014). The OECD gender initiative. Global Social Policy, 14(1), 123127.

Adema, W., del Carmen Huerta, M., Panzera, A., Thevenon, O., \& Pearson, M. (2009). The OECD family database: Developing a cross-national tool for assessing family policies and outcomes. Child Indicators Research, 2(4), 437-460.

Anderson, K. M. (2015). Social policy in the European Union. London: Palgrave.

Bennett. J. (2006). New policy conclusions from starting strong II: An update on the OECD early childhood policy reviews. European Early Education Research Journal, 14(2), 141-156.

Bonoli, G. (2013). The origins of active social policy: Labour market and childcare policies in a comparative perspective. Oxford: Oxford University Press. 
Cantillon, B., \& Van Lancker, W. (2013). Three shortcomings of the social investment perspective. Social Policy and Society, 12(4), 553-564.

Chowdhury, S., Vergeer, P., Schmidt, H., Barroy, H., Bishai, D., \& Halpern, S. (2013). Economics and ethics of results-based financing for family planning: Evidence and policy implications (Health, Nutrition, and Population (HNP) Discussion Paper). World Bank.

Daly, M. (2008). Whither EU social policy? An account and assessment of developments in the Lisbon social inclusion process. Journal of Social Policy, 37(1), 1-19.

Daly, M. (2020). Gender inequality and welfare states in Europe. Cheltenham, UK: Edward Elgar.

De la Porte, C. (2018). EU social policy and national welfare state reform. In B. Greve (Ed.), The Routledge handbook of the welfare state (2nd ed., pp. 477-487). Abingdon, UK: Routledge.

Deacon, B., \& Kaasch, A. (2008). The OECD's health and social policy: Neoliberal stalking horse or balancer of social and economic objectives? In R. Mahon \& S. McBride (Eds.), The OECD and transnational governance (pp. 226-241). Vancouver, Canada: University of British Columbia Press.

Ellinas, A. A., \& Suleiman, E. N. (2011). Supranationalism in a transnational bureaucracy: The case of the European Commission. JCMS: Journal of Common Market Studies, 49(5), 923-947.

Esping-Andersen, G., with Gallie, D., Hemerijck, A., \& Myles, J. (2002). Why we need a new welfare state. Oxford: Oxford University Press.

European Commission. (1989). Communication from the Commission on family policies. COM (89) 363 final. Brussels.

European Commission. (1994). The demographic situation of the European Union. COM (94) 595 final. Brussels.

European Commission. (2006). The demographic future of Europe-From challenge to opportunity. COM (2006) 571 final. Brussels.

European Commission (2013). Towards social investment for growth and cohesionIncluding implementing the European social fund 2014-2020. COM (2013) 83 final. Brussels.

European Commission. (2018). European pillar of social rights. Luxembourg: Publications Office of the EU.

European Union. (2019, July 12). Directive (EU) 2019/1158 of the European Parliament and of the Council of 20 June 2019 on work-life balance for parents and carers and repealing Council Directive 2010/18/EU. http://data.europa.eu/eli/dir/2019/ $1158 /$ oj.

Fiszbein, A., \& Schady, N. (2009). Conditional cash transfers: Reducing present and future poverty. Washington, DC: World Bank.

Hantrais, L. (1995). Social policy in the European Union. Winchester, Hampshire: Macmillan. 
Hantrais, L. (1997). Exploring relationships between social policy and changing family forms within the European Union. European Journal of Population/Revue Européenne de Démographie, 13(4), 339-379.

Jacquot, S. (2015). Transformations in EU gender equality: From emergence to dismantling. London: Palgrave Macmillan.

Jenson, J. (2008). Writing women out, folding gender in: The European Union 'modernises' social policy. Social Politics: International Studies in Gender, State and Society, 15(2), 1-23.

Jenson, J. (2009). Lost in translation: The social investment perspective and gender equality. Social Politics: International Studies in Gender, State and Society, 16(4), 446-483.

Jenson, J. (2010). Ideas and Policy: The EU considers social policy futures. ACES Case \# 2010.2. Washington, DC: EU Center of Excellence. Available at: https://www.academia.edu/20627636/Ideas_and_Policy_The_European_ Union_Considers_Social_Policy_Futures.

Jenson, J. (2017a). Developing and spreading a social investment perspective: The World Bank and the OECD compared. In A. Hemerijck (Ed.), The uses of social investment (pp. 207-215). Oxford: Oxford University Press.

Jenson, J. (2017b). The new maternalism. Children first, women second. In Y. Ergas, J. Jenson \& S. Michel (Eds.), Reassembling motherhood. procreation and care in a globalized world (pp. 269-286). New York: Columbia University Press. Jenson, J. \& Nagels, N. (2018). Social policy instruments in motion. Conditional cash transfers from Mexico to Peru. Social Policy \& Administration, 52(1), 323342.

Jenson, J. \& Sineau, M. (Eds). (2001). Who cares? Women's work, childcare and welfare state redesign. Toronto: University of Toronto Press.

King, T. (2007). Family planning and the World Bank in Jamaica. In W. C. Robinson \& J. A. Ross (Eds.), The global family planning revolution: Three decades of population policies and programs (pp. 155-174). Washington, DC: The World Bank.

Knijn, T., \& Smit, A. (2009). Investing, facilitating, or individualizing the reconciliation of work and family life: Three paradigms and ambivalent policies. Social Politics. International Studies in Gender, State and Society, 16 (4), 484-518.

Leimgruber, M., \& Schmelzer, M. (Eds.). (2017). The OECD and the international political economy since 1948. Cham: Palgrave Macmillan.

Mahon, R. (2008). Babies and bosses: Gendering the OECD's social policy discourse. In R. Mahon \& S. McBride (Eds.), The OECD and transnational governance (pp. 260-275). Vancouver, Canada: University of British Colombia Press.

Mahon, R. (2019). Broadening the social investment agenda: The OECD, the World Bank and inclusive growth. Global Social Policy, 19(1-2), 121-138.

Mahon, R., \& McBride, S. (Eds.). (2008). The OECD and transnational governance. Vancouver: University of British Columbia Press. 
Nieuwenhuis, R., Need, A., \& Van Der Kolk, H. (2012). Institutional and demographic explanations of women's employment in 18 OECD countries, 1975-1999. Journal of Marriage and Family, 74(3), 614-630.

OECD. (1994). New orientations for social policy. Social Policy Studies, \#1, OECD.

OECD. (1997). Beyond 2000: The new social policy agenda. Summary of the highlevel conference held at the Chateau de la Muette, Paris, 12-13 November 1996. Paris, France: OCDE/GD(97)66.

OECD. (1998, June 23-24). Background documents: The caring world: An analysis. Note by the secretary-general for meeting of the Employment, Labour and Social affairs Committee at Ministeral Level on Social Policy. Paris, France: OECD.

OECD. (1999). A caring World: The new social policy agenda. Paris, France: OECD.

OECD. (2007). Babies and bosses: Reconciling work and family life: A synthesis of findings for OECD Countries. Paris, France: OECD.

OECD. (2009). Doing better for children. Paris, France: OECD.

OECD. (2011a). Doing better for families. Paris, France: OECD.

OECD. (2011b). The future of families 2030: A synthesis report. Paris, France: OECD.

OECD. (2014). All on board: Making inclusive growth happen. Paris, France: OECD.

OECD. (2015). Final synthesis: New approaches to economic challenges. prepared for meeting of the OECD Council at the Ministerial Level Paris 3-4 June http:// www.oecd.org/naec/Final-NAEC-Synthesis-Report-CMIN2015-2.pdf.

OECD. (2017). Starting strong 2017. Key OECD indicators on early childhood education and care. Paris, France: OECD.

Psacharopoulos, G. (1995). Building human capital for better lives. Washington, DC: World Bank.

Rao, V., \& Woolcock, M. (2007). The disciplinary monopoly in development research at the World Bank. Global Governance, 13(4), 479-484.

Ringel, A. D. (1993). The population policy debate and the World Bank: Limits to growth vs. supply-side demographics. Georgetown Environmental Law Review, 6(1), 213-249.

Robinson, W. C., \& Ross, J. A. (Eds.). (2007). The global family planning revolution: Three decades of population policies and programs. Washington, DC: The World Bank.

Ross, G. (2001). Europe: An actor without a role. In J. Jenson \& M. Sineau (Eds.), Who cares? Women's work, childcare and welfare state redesign (pp. 177-213). Toronto: University of Toronto Press.

Saraceno, C. (2015). A critical look to the social investment approach from a gender perspective. Social Politics: International Studies in Gender, State and Society, 22(2), 257-269.

Saraceno, C. (2018). Family policies. In B. Greve (Ed.), The Routledge handbook of the welfare state (2nd ed., pp. 433-456). London: Routledge.

Smyth, I. (1996). Gender analysis of family planning: Beyond the feminist vs. population control debate. Feminist Economics, 2(2), 63-86. 
Stalford, H. (2002). Concepts of family under EU law-lessons from the ECHR. International Journal of Law, Policy and the Family, 16 (3), 410-434.

Stratigaki, M. (2004). The cooptation of gender concepts in EU policies: The case of "reconciliation of work and family". Social Politics: International Studies in Gender, State and Society, 11(1), 30-56.

Vetterlein, A. (2007). Economic growth, poverty reduction, and the role of social policies: The evolution of the World Bank's social development approach. Global Governance, 13(4), 513-533.

Weaver, C. (2007). The World's bank and the Bank's world. Global Governance, 13(4), 493-512.

Whitworth, S. (1994). Feminism and international relations. London: Palgrave Macmillan.

Wolfe, R. (2008). From reconstructing Europe to constructing globalization: The OECD in historical perspective. In R. Mahon \& S. McBride (Eds.), The OECD and transnational governance (pp. 25-42). Vancouver, Canada: University of British Colombia Press.

World Bank. (1980). World Development Report 1980. Washington, DC: World Bank.

World Bank. (1995). Investing in people: The World Bank in action. Washington, DC: World Bank.

World Bank. (2019). World development report 2019: The changing nature of work. Washington, DC: World Bank.

Open Access This chapter is licensed under the terms of the Creative Commons Attribution 4.0 International License (http://creativecommons.org/licenses/by/4.0/), which permits use, sharing, adaptation, distribution and reproduction in any medium or format, as long as you give appropriate credit to the original author(s) and the source, provide a link to the Creative Commons licence and indicate if changes were made.

The images or other third party material in this chapter are included in the chapter's Creative Commons licence, unless indicated otherwise in a credit line to the material. If material is not included in the chapter's Creative Commons licence and your intended use is not permitted by statutory regulation or exceeds the permitted use, you will need to obtain permission directly from the copyright holder.

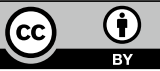

